\title{
Efficient Compound Barge Design
}

\author{
Glib Ivanov ${ }^{1}$ \\ (Received: 07 February 2021 / Revised: 05 March 2021 / Accepted: 08 April 2021)
}

\begin{abstract}
The ropes used to secure the pusher to a barge were prone to tearing; this problem was remedied by the development of several coupling devices, including one that was highly advanced. Previous researchers have identified three major issues regarding this matter: the vessel's seaworthiness when not coupled, safety, and suboptimal structure. The purpose of this paper is to propose solutions to the aforementioned problems by introducing an efficient compound vessel design. Comparative advantages of compound vessels are analysed. Designs of a compound barge and effective coupling mechanism are introduced. Prospective weight reduction and economic advantages of coupled barges are calculated and analysed.
\end{abstract}

Keywords—tug-barge, coupler, barge, compound vessel, weight, design, analysis.

\section{INTRODUCTION}

$\mathrm{D}$ uring the 20th century, naval architects sought to improve pusher tug operations. The ropes used to fasten the pusher to a barge were prone to tearing off; this problem was solved by the invention of various coupling mechanisms, for example, a quite advanced mechanism, patented by Boris Stankov [1]. This approach has not only lead to improved coupling robustness, but also in a significant reduction in vessel resistance, and thus, increase in speed and/or reduction of transportation cost (up to $34 \%$ reduction) [2].

\section{A. Literature Review}

During recent years several papers were published on the research of coupled vessels.

O.G. Yegorova argues in « Structure improvement of dry bulk river barges for system "Danube-Main-Rhein" » that longitudinal strength is very important for this type of vessels, and proposes to use longitudinal hull structure. She noted that due to wear during cargo and lock operations, side plating always has to be thicker than on other ships, and that it has a positive impact on longitudinal strength.[4]

A.G. Yegorov has compiled and analysed different types of obsolete and current pusher-barge coupling devices in his paper [5]. He has classified the coupling devices into three categories by their mechanics:

- $\quad$ Rigid - not allowing coupled vessels to move or rotate in reference to each other while coupled.

- Semi-flexible - allowing for one or several degrees of freedom.

- $\quad$ Flexible - allowing all degrees of freedom - rope or similar.

He concluded, that for sea-going barges, semi-flexible (able to rotate around an axis) devices are of greatest efficiency.

A. Yegorov had also proposed a compound vessel consisting of a cargo vessel and a coupled barge, and calculated its maximum length if navigating in river
Dnipro, as well as estimated its benefits and bright prospects for the modern Black Sea cargo industry.[6]

Finally, the year 2019 US Patent No. US10359023B2 authored by Robert C. Murtha JR., Michael E. McCormick. [7] Authors proposed a way to convert waves mechanical energy to the movement of hydraulic cylinders, powering onboard devices such as pumps. The mechanism involves three sections of a barge, each with different hull shapes, coupled together, and hydraulic cylinders. The hull structure and coupling method were not fully de-scribed, as the purpose of the device was to obtain energy from waves, yet, this method could be used to as an additional advantage when assessing the benefits of coupled barge design.

M.Y. Alferyiev in the book "Seaworthiness and manoeuvrability of vessels. Water resistance to ship movement" [14], had described different kinds of bargetug "trains" and methods of determining their resistance. He showed, that in the vast majority of cases, a train resistance is lower than the combined resistance of the barges and a tug moving at a distance due to hydrodynamic effects. Alferyiev differentiated between two principal types of vessels used in tug-barge trains - a barge with hull conforming as close as possible to the tug it is connected with, and a barge that has a conventional (comparatively seaworthy) hull shape. He then proves that conforming hull barges have lower resistance.

\section{B. Problems}

The three main problems pointed out by previous researchers are the following:

1) Vessel's seaworthiness when not coupled.

To minimize the resistance, two coupled vessels' hull shape is altered to fit closer to each other. For example, the stem of a pusher is made completely vertical, or if the tug shape is kept relatively seaworthy, the barge shape has to become the opposite [1]. When decoupled, this hull shape is suboptimal in regards to seaworthiness.

\section{2) Safety.}

The rigid coupling of a barge and a tug has itself been a reason for accidents. [5] The most famous case is, perhaps, the Bolsheretzk (Большерецк) catastrophe in 1979 
[3]. The tug had been pushing a barge loaded with timber, the barge had capsized during a storm, and the tug crew could not have decoupled the vessel in time as the barge brought the rigidly-coupled tug down into the sea; all the crew members died.

3) Suboptimal structure.
The barge for a pusher is usually made as long as the waterway conditions permit. Its length and width, as well as its wide deck opening (most of the barges carry bulk cargo e.g. grain) mandate exceptionally strong longitudinal stiffeners, decreasing cargo capacity and increasing construction cost.

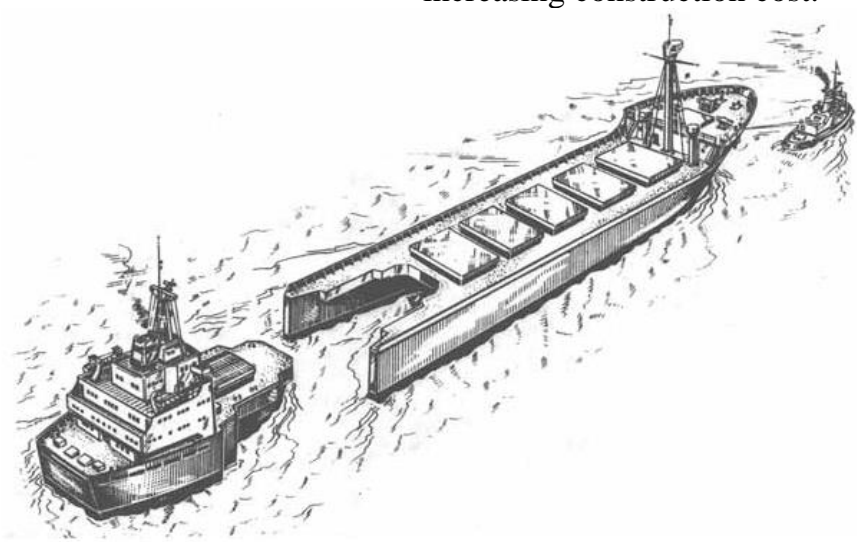

Figure. 1. Unorthodox conforming pusher-tug and barge combination (Source: seaships.ru).

The purpose of this paper is to propose solutions to the aforementioned problems by introducing an efficient compound vessel design.

\section{METHOD}

The data for this paper was gathered around the internet (on companies' official websites, scientific papers, pa-tents and classification society rules) and in relevant books. Data analysis was performed on the sampled data. Then in the latter half of the results, calculations were made according to structural mechanics methods, standard in the industry, such as free body diagrams etc. Drawing were made according to author's experience with similar vessels.

TABLE 1.

ADVANTAGES AND DISADVANTAGES OF DIFFERENT KINDS OF COUPLED VESSELS

\begin{tabular}{lccc}
\hline Pusher coupled with barge & Cargo ship with a trailer & Two (or more) coupled barges \\
\hline + Widely-adopted and studied & + Added cargo capacity & + Reduced hull weight \\
- Prone to accidents & - Inaccessibility of the trailer unless good & + Simpler coupling mechanism as no crew \\
& weather (for sea vessels) & & safety is required \\
- Suboptimal decoupled performance & - Propulsion positioning problem, bad & Designed to operate well even when \\
decoupled & decoupled performance & Can pass locks 1 by 1 \\
\hline
\end{tabular}

\section{RESULTS}

\section{A. Preliminary analysis}

The objective was to design vessels that would evade the problems mentioned in the introduction while retaining the benefits of compound vessels:

- Reduced resistance in comparison to similar vessels operating separately;

- The ability for at least one of the coupled vessels to be without propulsion system and unmanned.

On the preliminary design stages, three types of coupled vessels shown on Fig. 1,2 and 3 were considered and their comparative advantages analysed in table 1.

For widely-adopted pusher + barge configuration, the problems were identified in the introduction, they are: safe-ty concerns and suboptimal seaworthiness when decoupled.

Cargo ship with an additional "trailer" barge, while providing additional cargo capacity, has following problems: if the trailer is placed in front of the main vessel - navigation is made more difficult, as the forward segment obscures view, especially as the wave height goes up. It also becomes a challenge to turn, moor and anchor. In case mooring or anchoring in less than desired weather conditions is required, it's evident the front part of the ship e.g. trailer has to be accessed to perform mooring operations, however, it becomes increasingly dangerous as both parts of the vessel pitch in different directions, rendering the trailer inaccessible and deck operations impossible.

In case the trailer is placed behind the vessel - a problem arises where to place the propeller for it to operate efficiently, also mooring is still a problem as in forward position. These vessels could only be safely used in calm inner waters.

In case several barges are coupled together, the following advantages unique to them, as opposed to other 2 kinds of compound vessels, also appear:

- No crew is present on the barges during navigation, meaning in case of an accident, no life will be lost. It enables the adoption of another coupling device design: one, which, albeit it cannot be quickly decoupled, is simpler and cheaper.

- When passing a lock, both pusher-barge and compound barge hulls could be decoupled and towed through the $\operatorname{lock}(\mathrm{s})$ one at a time, then coupled back 
together. However, it requires the coupling operation to be performed easily. To make use of this advantage, certain coupling devices described in [5] can be used.

Having assessed the advantages and disadvantages, I concluded that coupled barges should be developed as opposed to other types of coupled vessels. The weight benefit and devices design are explained in the following chapters.

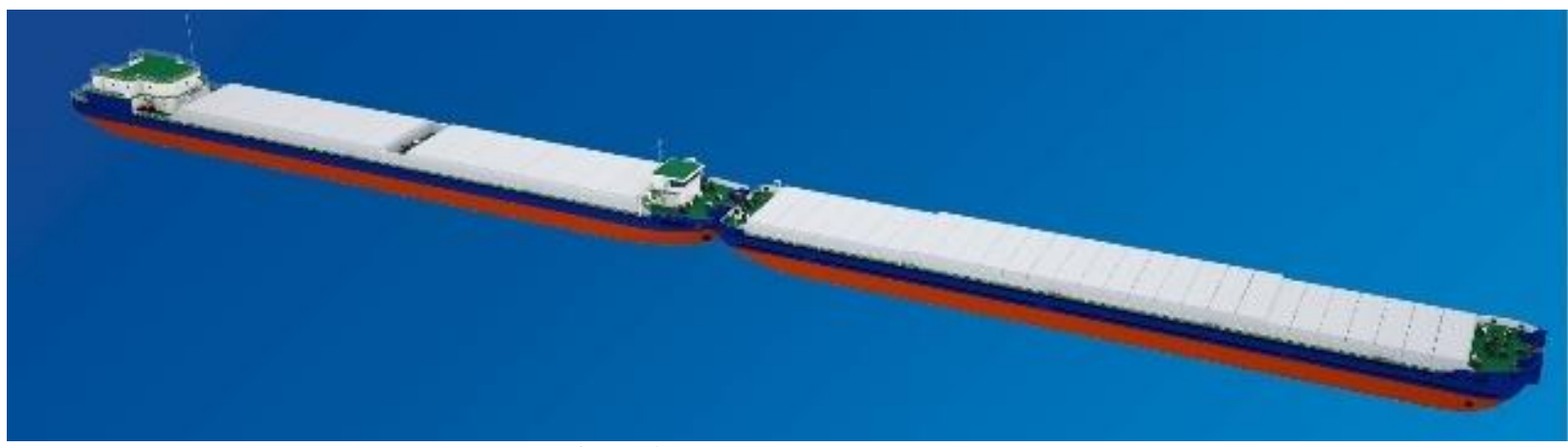

Figure. 2. Compound cargo ship RSD67

Source: Marine Engineering Bureau (meb.com.ua)

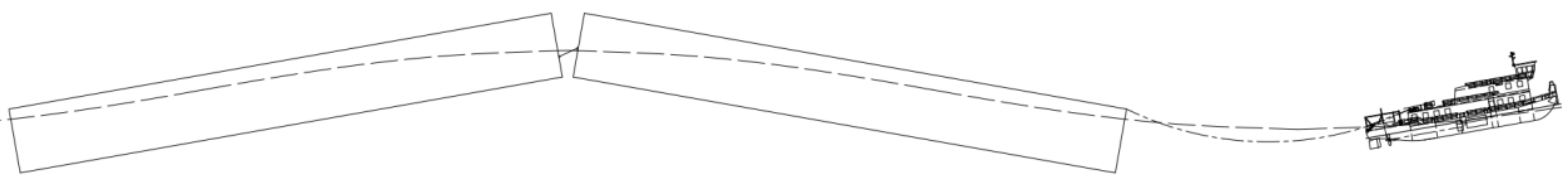

Figure. 3. Compound barge.

\section{B. Reducing Resistance - Cover Design}

The proposed solution for the bad decoupled performance problem is the following:

Both rear and forward vessels hulls are designed and constructed with seaworthiness and other characteristics in mind, the hull shape below the waterline is not altered because the vessels are coupled, unlike conventional designs.

In order to smoothen the hull (hide the opening between vessels), a flexible cover, e.g. made of resin, is introduced. It is attached to the forward hull in its aft region where the hull starts to curve. The cover acts as if the plating was continuous and no opening was present.

The cover is only attached on the forward vessel and freely touches the rear vessel hull, an overhang is left, to ensure the cover still comes in contact with the rear hull when the two vessels are on the opposite side of a wave crest or through.

The space between the vessels is still filled with water as the cover is not watertight, the water pressure in this space acts to counterbalance the outside water pressure to prevent the cover from buckling in too much into the space.

A schematic representation of bottom part of this design at centre plane section when on wave crest (thus curved waterline WL) is shown on Fig. 4, note the overhang cover length stretching over the rear hull in this situation.

The cover can be made of single or fused pieces of material and spans across starboard, portside and bottom, in a $U$ shape as shown on Fig. 5, this gives the frame some degree of rigidness that prevents excessive buckling under own weight.
The cover can be attached to the forward hull in the following fashion shown on Fig. 6.

In the aft region, where the shell begins to curve, a pressing plate (plank) is welded to the inner side of the hull; it is placed close to a stiffener, so as to have enough robustness. Another pressing plate is manufactured with curved edges to minimize resistance and placed outside. The flexible cover is pressed tight between the two plates while the plates are fastened together by bolts, placed in a checkerboard fashion. For the fastening while submerged, the outer pressing plate has a dead-end thread.

Deinstallation procedure:

1. Hook the outer shell to the ship's derricks or cranes;

2. Unscrew the bolts to the position where they no longer hold the outer plank and cover together, but not fully, as to prevent water from getting inside the hull;

3. Take the cover and outer plank away for storage.

Bolts are labour-intensive while sustaining the ability to remove the cover easily when decoupling. The cover should be used with consideration of how often the hulls will be decoupled. The cover is designed with a condition that coupling/decoupling operations will not be done too often.

As a better alternative to bolt fastening, a device could be installed on deck on both boards to press the outer plank and resin cover to the deck, its design is out of the scope of this paper.

As a result of not having alternated the hull shape, good seaworthiness is achieved while decoupled; by using the cover, optimal seaworthiness is achieved while coupled as if there was no gap between the ships. 


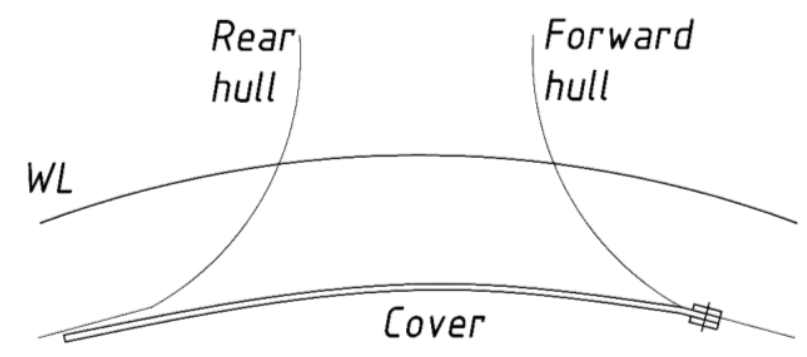

Figure 4. Cover schematic, centre plane section
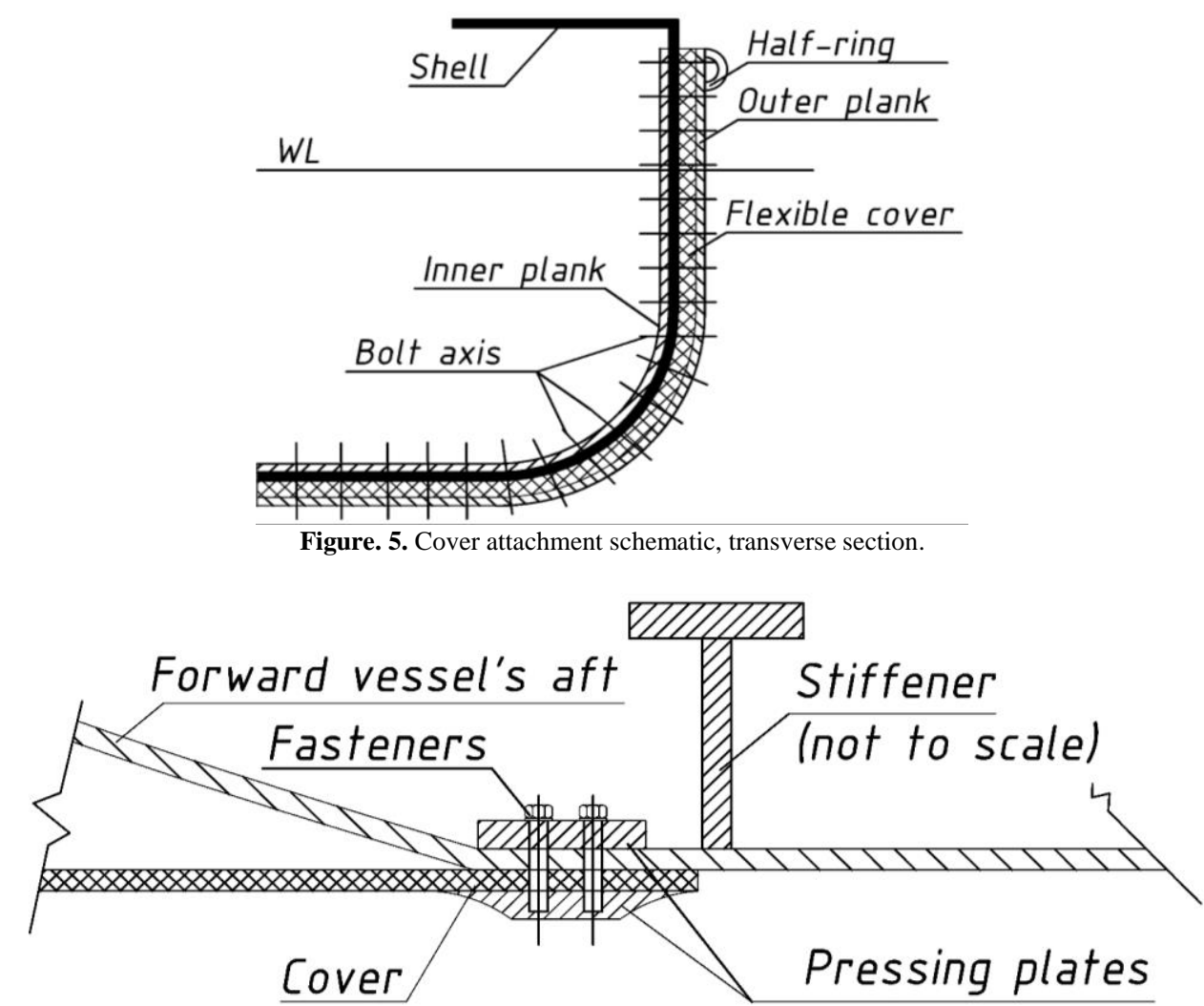

Figure 6. Cover attachment schematic, longitudinal section.

\section{Coupling Mechanism Design}

\section{Design requirements}

The coupling mechanism was designed with the following criteria in mind as derived from the preliminary analysis:

- It should be relatively simple and cost-effective;

- It must be at least of semi-flexible type (at least able to rotate around a horizontal perpendicular axis)

- It should withstand loads, be reliable and autonomous;

The design process started with choosing the initial conditions. The compound barge would function to transport grain from a river or a coastal port to a cargo ship waiting at an out of the port anchorage, as is customary for grain cargo operations. An existing B5000 type riversea dry bulk barge was chosen as a prototype [8], shown on Fig. 7. Here are the principal characteristics of this barge:

Length: $101 \mathrm{~m}$

Draught: $3.65 \mathrm{~m}$

Displacement: $6207 \mathrm{~T}$
Width: $17.2 \mathrm{~m}$

Deadweight: 5007T

Height: $5.75 \mathrm{~m}$
Cargo capacity: $7000 \mathrm{~m}^{3} \quad$ Class: K*Ice B-R4-RS2.5

To make the compound barge, B5000 was divided into two coupled parts, $50 \mathrm{~m}$ each (excl. coupling device length). The displacement, deadweight and cargo capacity were halved.

The prototype has RS2.5 class which allows it to operate in wave conditions with maximum wave height $2.5 \mathrm{~m}$ at $3 \%$ overtopping chance, these conditions are used in wave bending moment calculation in chapter $\mathrm{V}$. However, as there is a chance the ship may find herself in harsher wave conditions, the force acting on the rear hull is deter-mined as for the coupling mechanism's bearings to withstand it without decoupling if damaged. The torsional load is not calculated as it is neglectable at wave height $2.5 \mathrm{~m}$. At the harsher wave conditions, the one-time torsional load can deform the bearing rods, but not bearings proper and it said not to lead to the hulls decoupling.

\section{Loads calculation}

Based on the marine weather data provided by RMRS [9], the shortest wave length in North-Western Black Sea 
is $79 \mathrm{~m}$, while wave height with $1 \%$ overtopping chance in 5 years is equal to 7 meters. The calculated wave angle is 10 degrees. It is considered to be the biggest angle the ship could encounter.

The general scheme of the compound vessel at sea is shown on Fig. 8. Two compound barges situated on a wave crest are towed by a tug. Waterline shown dashed; tug line shown dashed-dotted. Barges shown as rectangles.

There are four forces acting on the rear hull of the compound vessel, as shown on Fig. 9:

D - Gravity force;

$\mathrm{R}$ - Vessel resistance, determined by analytical or experimental methods, acting along the surface;

$\mathrm{N}$ - Reaction of a water body, normal to the water surface;

F - Pull (reaction) of the coupling mechanism.

$\mathrm{D}=\mathrm{mg}=\mathrm{Ny}=\mathrm{N} \cos \alpha$, where $\alpha-$ wave angle

$$
\begin{aligned}
& \sum F_{y}=N_{y}-D-R_{y}=0 \\
& \sum F_{x}=N_{x}+R_{X}-F=0 \\
& N_{y}=D+R_{y} \\
& N_{x}=N_{y} \operatorname{tg} \alpha \\
& F=N_{y} \operatorname{tg} \alpha+R_{x} \\
& F=(D+R \sin \alpha) \operatorname{tg} \alpha+R \cos \alpha
\end{aligned}
$$

After trivial transformations, the following equation for the pull $\mathrm{F}$, acting on the hull is derived. The reaction of the coupling device is then equal and opposite.

$$
F=D \operatorname{tg} \alpha+R / \cos \alpha
$$

In this case, $\mathrm{D}=3103 \mathrm{Tf}=30,440 \mathrm{kN} ; \alpha=10^{\circ}$; $\operatorname{Dtg} \alpha=5367 \mathrm{kN}$
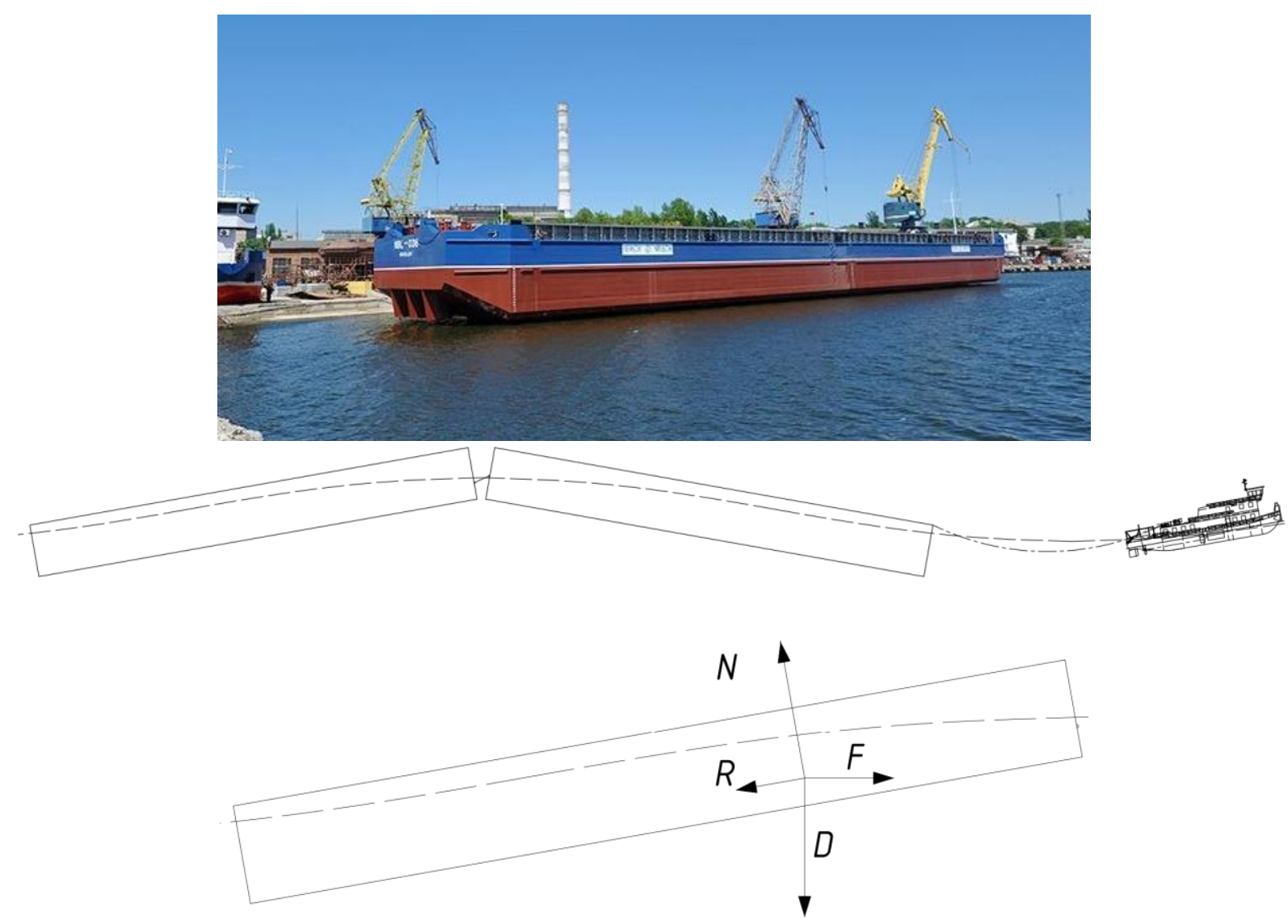

Figure 9. Free body diagram of the rear coupled hull. Dashed line denotes wavy water surface.

Resistance $\mathrm{R}$ can only be accurately determined with a towing tank test. However, as it plays a minor part as compared to gravity force, it can be approximated with the following formulas:

Full resistance consists of towing resistance and wave resistance:

$R=R_{T}+R_{W}$

Towing resistance [10]:

$$
R_{T}=S V^{2} / K, \mathrm{Tf}
$$

where $\mathrm{S}$ - underwater midship frame surface, $\mathrm{m} 2, \mathrm{~S}=$ $63 \mathrm{~m} 2$;

$\mathrm{V}$ - towing speed, $\mathrm{kn}, \mathrm{V}=10 \mathrm{kn}$;

$\mathrm{K}$ - coefficient determined by vessel type, for medium-sized cargo vessels $\mathrm{K}=438$

$R_{T}=141 \mathrm{kN}$ 
For the purpose of these calculations, waves are considered to be WMO wave grade 5, which is higher than the waves the vessel encounters during service.

Wave resistance [11]:

$$
R_{W}=1.45 h_{g} 10^{-6} L(1.7 T+\delta B) V^{2}, \mathrm{Tf}
$$

where hg - WMO wave grade, hg $=5 ; \mathrm{L}-$ ship length, $\mathrm{m} ; \mathrm{T}$ - ship draught, $\mathrm{m} ; \mathrm{B}-$ ship width, $\mathrm{m} ; \delta$ - block coefficient; $\mathrm{V}$ - ship speed, kn.

$$
R_{W}=8.07 \mathrm{kN}
$$

Total resistance:

$$
\begin{gathered}
R=R_{T}+R_{W}=149 \mathrm{kN} \\
R / \cos \alpha=151 \mathrm{kN} \\
\text { Coupling device reaction: } \\
F=D t g \alpha+R / \cos \alpha=5518 \mathrm{kN}
\end{gathered}
$$

With the force acting on the coupling device known, its parameters and configuration can now be determined.

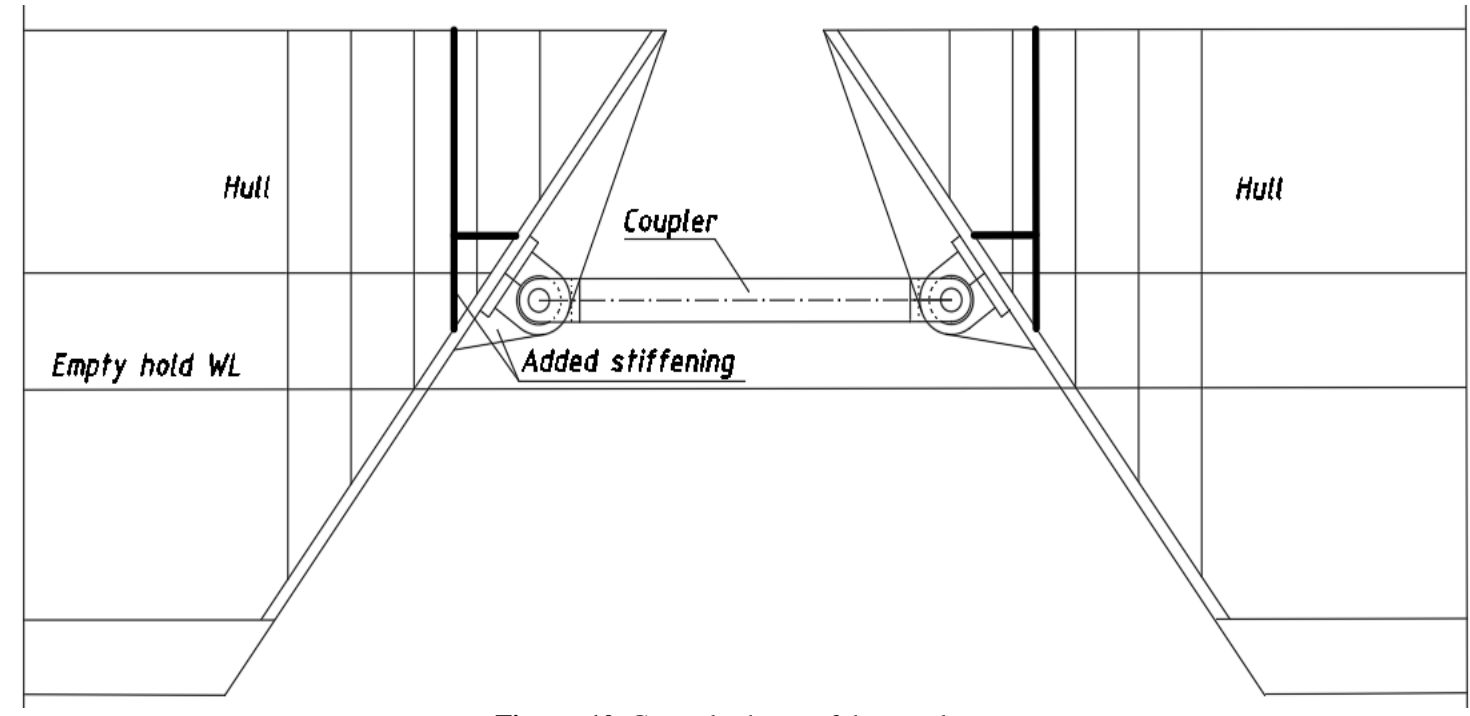

Figure. 10. General scheme of the coupler.

\section{Mechanism scheme}

The general scheme of the coupling is shown on Fig. 10 , bearings are placed near in the lower part of the vessel, as close to the neutral axis as exploitation factors permit, as to minimize loads on the structure. There are two couplers symmetrical about centreline plane.

It should be noted that this semi-flexible coupling allows rotation around the horizontal perpendicular axis as well as provides vertical and limited horizontal freedom of movement. As mentioned in the literature review, flexibility is important for evading loads caused by pitching, heaving and surging.

Fenders or a resin shell padding can be installed on the coupled hulls to prevent damage in case the vessels collide, these are not shown on the scheme as many designs are possible, while irrelevant to the function. Abutments could be installed to prevent hulls relative heaving and surging in case required. The system if an example and can be modified to add or reduce its degrees of freedom as long as it stays semi-flexible. As in the shown case, the vessel is not loaded and the coupling is situated above the actual waterline. The vessel is coupled while not loaded or in the dock, and the mechanism is covered in thick polyethene or similar cheap watertight material.
The measurements of the parts shown on Fig. 11 were determined with loads in mind according to trivial structural mechanics calculations.

A spherical roller bearing (1), SKF 22340 CC/W33 in this case, is installed in the casing (2), connected to the hull by bolts (additional support by integration with the hull is shown on Fig. 10). An axle (3) is fit in the bearing, its ends fixed in a fork (4). Fork and rod (5) make up a single cast element that connects the system to identical on the other hull; the rod is made of a rectangular shape to perform better at torsion. Spherical roller bearings were chosen to allow for slight $\left(1-3^{0}\right)$ rotation around the vessel's vertical axis to ease coupling while sway and yaw are present

Specifications:

Material: Alloy steel (E.g. 10KhSND, Re: $530 \mathrm{MPa}$ )

Bearing: SKF 22340 CC/W33

Axle diameter: $200 \mathrm{~mm}$

Rod section dimensions: $80 \mathrm{~mm}$ x $240 \mathrm{~mm}$

Distance between axles: $1000 \mathrm{~mm}$

Total weight of two couplers: $7.05 \mathrm{~T}$ 


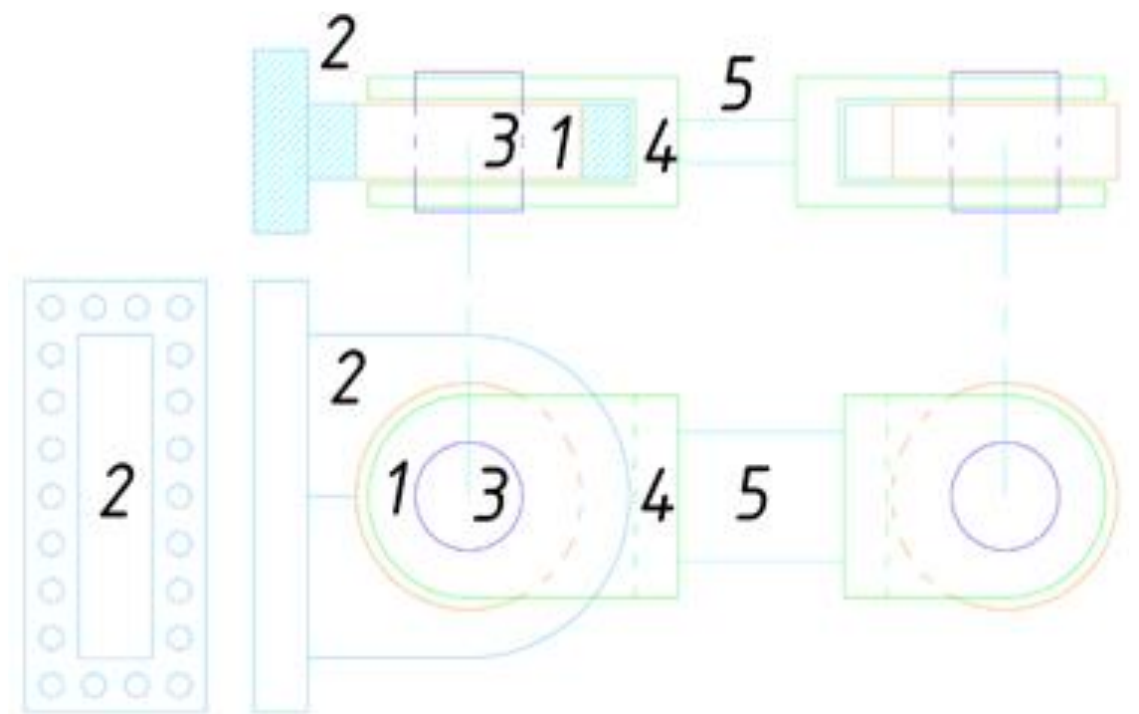

Figure. 11. Detailed coupling.

The coupling process is simple: Fit the axle (3) through the openings in the fork (4) and the bearing (1), then fasten it to the fork by means of preference, for example, the axle could be made in a form of a bolt then a nut will be fitted on the other side etc. As a result, a coupling scheme with principal dimensions is procured. The coupling allows for required flexibility and withstands actual loads and is cost-effective.

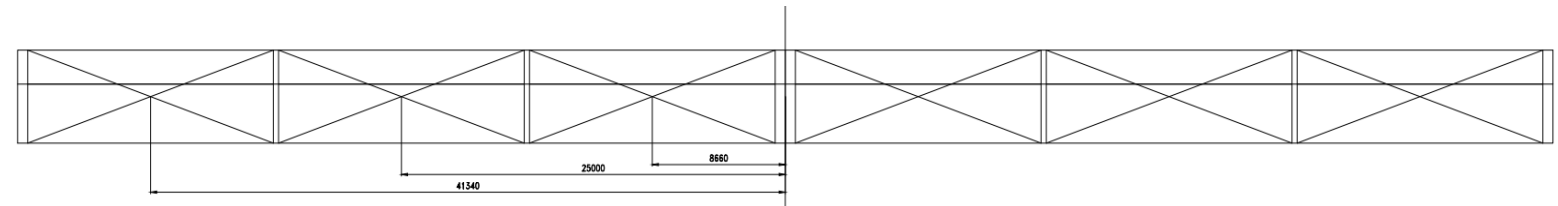

Figure. 12. Cargo holds scheme.

\section{Hull Weight Reduction}

1. Ship's bending moment calculation

In this part, weight is compared between the original 100

m R5000 vessel and the coupled vessel consisting of two parts of $50 \mathrm{~m}$. As the length of a ship increases, it requires unproportionally more longitudinal stiffness, provided by longitudinal stiffeners and plating, which increases weight drastically, as compared to a short vessel which chiefly employs perpendicular stiffeners to deal with local loads.

Firstly, loads are analysed in accordance with empiric formulas provided in A. Maximaji's book on hull strength [12].

Lightweight part of bending moment is found as:

$$
M_{L W}=k_{L W} g m_{L W} L, \mathrm{kNm}
$$

where $k_{\mathrm{LW}}=0.27 \delta^{1 / 3}$ for a barge, $k_{L W}=0.267$; $m_{L W}$ the mass of the empty hull, found as the difference between displacement and deadweight.

$$
\begin{aligned}
& m_{L W}^{50}=600 \mathrm{~T}, m_{L W}^{100}=1200 \mathrm{~T} \\
& M_{L W}^{50}=78,507 \mathrm{kNm} ; M_{L W}^{100}=314,029 \mathrm{kNm}
\end{aligned}
$$

Deadweight part of bending moment is found as the sum of static moments of deadweight elements respective to the middle plane, times $\mathrm{g}$ :

$$
M_{D W}=g \sum_{i} m_{i} x_{i}, \mathrm{kNm}
$$

Here only cargo is counted, as other weights can be neglected on a barge. The barge is divided into 6 cargo holds shown on Fig. 12. Each contains $1 / 6$ of DW $=835$ $\mathrm{T}$ of cargo. The results are presented in Table 2.

$M_{D W}^{50}=300,279 \mathrm{kNm} ; M_{D W}^{100}=1,226,715 \mathrm{kNm}$

The buoyancy force moment is found as:

$$
M_{B}=k_{B} \rho g V_{p} L, \mathrm{kNm}
$$

where $\mathrm{k}_{\mathrm{B}}=0.23$ at $\delta=0.96$;

volumetric displacement:

$$
V_{p}=D / 1.025, \mathrm{~m}^{3}
$$

$$
M_{B}^{50}=350,065 \mathrm{kNm} ; M_{B}^{100}=1,400,485 \mathrm{kNm}
$$

The bending moment caused by waves is determined in accordance with RMRS classification society rules [15]. It is defined as:

$$
M_{w}=190 c_{w} B L^{2} C_{b} \alpha 10^{-3}, \mathrm{kNm}
$$


TABLE 2.

\begin{tabular}{llll}
\multicolumn{5}{c}{ TABLE 2. } \\
\hline Hold & $\mathrm{m}, \mathrm{T}$ & $\mathrm{x}, \mathrm{m}$ & $\mathrm{T}$ x m \\
\hline 1 & 835 & 41.34 & 34,498 \\
2 & 835 & 25 & 20,863 \\
3 & 835 & 8.66 & 7,227 \\
4 & 835 & 8.66 & 7,227 \\
5 & 835 & 25 & 20,863 \\
6 & 835 & 41.34 & 34,498 \\
\hline & & Sum, Tfm & 125,175 \\
$100 \mathrm{~m}$ & & $\mathrm{M}$ Dw, $\mathrm{kNm}$ & $1,226,715$ \\
\cline { 3 - 4 } & & & $\mathrm{T} \times \mathrm{m}$ \\
Hold & $\mathrm{m}, \mathrm{T}$ & $\mathrm{x}, \mathrm{m}$ & 13,636 \\
1 & 835 & 16.34 & 1,669 \\
2 aft & 417 & 4 & 1,669 \\
2 fore & 417 & 4 & 13,636 \\
3 & 835 & 16.34 & 30,609 \\
\hline \multirow{2}{*}{$50 \mathrm{~m}$} & & Sum, Tfm & 300,279 \\
\cline { 3 - 4 } & & &
\end{tabular}

where section coefficient $\alpha=1$ for midships section; wave coefficient:

$90 \mathrm{~m}$;

$$
c_{w}=0.0856 L-\text { for ships length under }
$$

for ships length between $90 \mathrm{~m}$ and $300 \mathrm{~m}$;

$c_{w}=10.75-\left(\frac{300-L}{100}\right)^{3 / 2}$

The wave bending moment is then multiplied by a reduction coefficient, which for class $\mathrm{R} 4$ vessels equals:

$\varphi_{r}=0.6-0.2 L / 100$

$$
M_{w}^{50}=16,862 \mathrm{kNm} ; M_{w}^{100}=99,867 \mathrm{kNm}
$$

The summary bending moment is the sum of $\mathrm{M}_{\mathrm{cw}}$ and $\mathrm{M}_{\mathrm{w}}$ and is respectively:

$$
M^{50}=31,192 \mathrm{kNm} ; M^{100}=170,622 \mathrm{kNm}
$$

As convened [13], the ship hull is said to be equivalent to a beam. Its necessary moment of resistance is found as

$$
W_{\text {req }}=10^{3} \times \mathrm{M} / \sigma_{a l}, \mathrm{~cm}^{3}
$$

where $\mathrm{M}$ - resultant moment at middle section; $\sigma_{\mathrm{al}}$ - maximum permissible stress caused by alternating load, $\sigma_{\mathrm{al}}=76 \mathrm{MPa}$.

$$
W^{50}=410425 \mathrm{~cm}^{3} ; W^{100}=2245022 \mathrm{~cm}^{3}
$$

\section{Hull weight estimation}

To determine the weight as accurately as possible, two midship sections (shown on Fig. 13) were drawn with their longitudinal hull strength providing the required moment of resistance. The prototype vessel drawings are not available, so the sections were drawn in resemblance to the general arrangement of similar barges in Ukraine. Both longitudinal and transverse elements size was estimated and calculated according to the RMRS rules [15]. An assumption is made that all the plate elements are of equal thickness along with the ship, which is often true for older vessels.

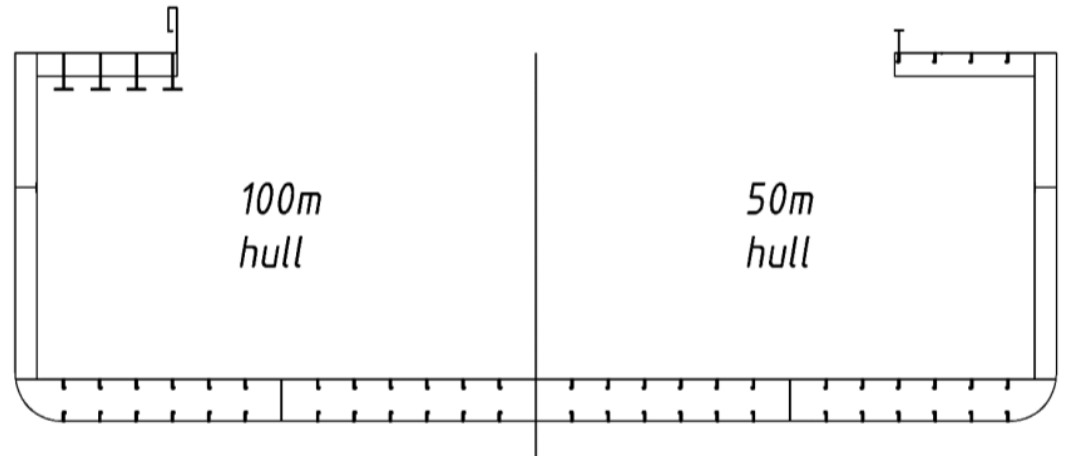

Figure. 13. Midship sections.

The equivalent girders moment of resistance at deck level calculations are presented in tables 3 and 4 for 100 $\mathrm{m}$ and $50 \mathrm{~m}$ vessels respectively. There are two points worth noting:

For the purpose of this comparison, the element's dimensions (e.g. thickness and height) were manipulated to attain the required moment. The general shape of the hull, as well as its elements, was kept as similar as possible between $50 \mathrm{~m}$ and $100 \mathrm{~m}$ hulls, as for the comparison to be more natural. In the actual design of such vessels, a $100 \mathrm{~m}$ hull would differ more from a $50 \mathrm{~m}$ hull, notably in width, deck girders and coaming e.g. a higher coaming and a box-girder might be installed on a $100 \mathrm{~m}$ ship, while a $50 \mathrm{~m}$ 
ship would be designed with less width for stability and resistance purposes.

The actual bending moment of $50 \mathrm{~m}$ hull exceeds the required, but it could not be lowered much more because of minimal girder parameters for transverse elements support. This makes the weight bigger, thereby not affecting the credibility of the weight reduction result.

Hull drawing was produced according to calculations and estimations, shown on Fig. 14

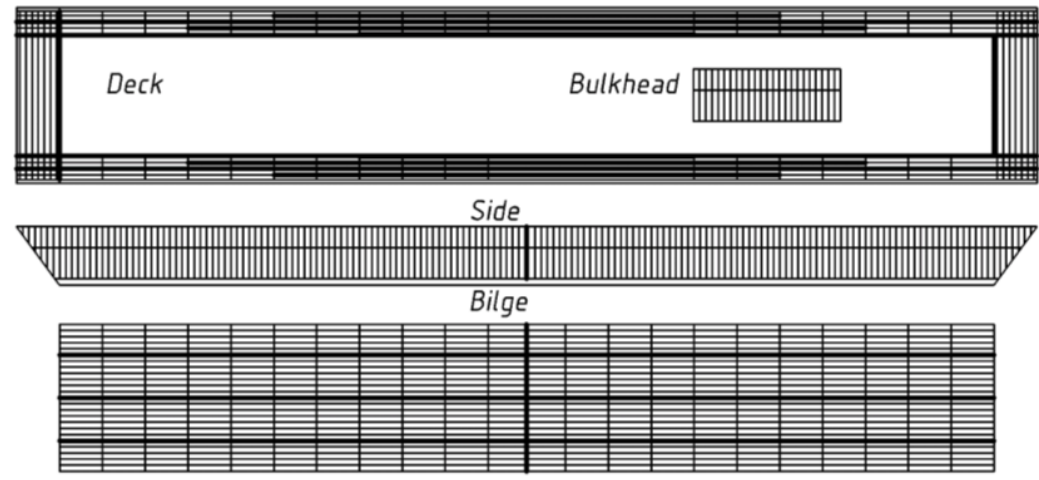

Figure 14. $100 \mathrm{~m}$ hull drawing.

TABLE 3.

EQUIVALENT GIRDER CALCULATION FOR 100M VESSEL

\begin{tabular}{|c|c|c|c|c|c|c|c|c|c|}
\hline \multirow{2}{*}{$\begin{array}{l}\text { № } \\
1\end{array}$} & \multirow{2}{*}{$\begin{array}{l}\text { Element } \\
\text { Bottom plating }\end{array}$} & \multirow{2}{*}{$\begin{array}{r}\text { Q- } \\
1\end{array}$} & \multicolumn{2}{|c|}{ Dimensions, cm } & \multirow{2}{*}{$\begin{array}{r}\mathbf{F}_{\mathbf{i}}, \mathbf{c m}^{\mathbf{2}} \\
1256\end{array}$} & \multirow{2}{*}{$\begin{array}{r}\mathbf{Z}_{\mathbf{i}}, \mathbf{c m} \\
0.5\end{array}$} & \multirow{2}{*}{$\begin{array}{r}\mathbf{F z}_{\mathbf{i}}, \mathbf{c m}^{\mathbf{3}} \\
628\end{array}$} & \multirow{2}{*}{$\frac{\mathbf{F Z}^{2}, \mathbf{c m}^{\mathbf{4}}}{314}$} & \multirow{2}{*}{$\frac{\mathbf{i}_{\mathbf{c}}, \mathbf{c m}^{\mathbf{4}}}{268}$} \\
\hline & & & 1.6 & 785 & & & & & \\
\hline 2 & Double bottom plating & 1 & 1 & 859 & 859 & 65 & 55835 & $3,629,275$ & 72 \\
\hline 3 & Bilge strake & 1 & 1.6 & 100 & 160 & 22 & 3520 & 77,440 & 66,667 \\
\hline 4 & Side plating & 1 & 1.6 & 290 & 464 & 283 & 131,312 & $37,161,296$ & $3,251,867$ \\
\hline 5 & Sheer strake & 1 & 2.5 & 210 & 525 & 470 & 246,750 & $115,972,500$ & $1,929,375$ \\
\hline 6 & Deck plating & 1 & 2.5 & 260 & 650 & 575 & 373,750 & $214,906,250$ & 339 \\
\hline 7 & Bottom stringers & 12 & \multicolumn{2}{|c|}{ HP14 ${ }^{\mathrm{a}}$} & 168.6 & 9.5 & 1,602 & 15,216 & 3,252 \\
\hline 8 & DB stringers & 12 & \multicolumn{2}{|c|}{ HP14 ${ }^{\mathrm{a}}$} & 168.6 & 58 & 9,779 & 567,170 & 3,252 \\
\hline 9 & Keel & 1.5 & 2 & 65 & 195 & 32.5 & 6,338 & 205,969 & 45,771 \\
\hline 11 & Side stringer hor. & 1 & 1.6 & 35 & 56 & 365 & 20,440 & $7,460,600$ & 5,717 \\
\hline 12 & Side stringer vert. & 1 & 2 & 15 & 30 & 365 & 10,950 & $3,996,750$ & 10 \\
\hline 13 & Carling vert. & 4 & 2 & 55 & 440 & 547 & 240,680 & $131,651,960$ & 27,729 \\
\hline 14 & Carling hor. & 4 & 3 & 30 & 360 & 518 & 186,480 & $96,596,640$ & 68 \\
\hline 15 & Coaming vert. & 1 & 2 & 70 & 140 & 610 & 85,400 & $52,094,000$ & 57,167 \\
\hline 16 & Coaming outer vert. & 1 & 2 & 35 & 70 & 627 & 43,890 & $27,519,030$ & 7,146 \\
\hline 17 & Coaming stiffener & 1 & 3 & 15 & 45 & 610 & 27,450 & $16,744,500$ & 34 \\
\hline \multirow[t]{4}{*}{18} & Coaming hor. & 1 & 3 & 30 & 90 & 646 & 58,140 & $37,558,440$ & 68 \\
\hline & & & & & 5677 & & $1,502,943$ & $746,157,350$ & $\mathbf{5 , 3 9 8 , 7 9 8}$ \\
\hline & & & & & \multicolumn{2}{|l|}{$\mathbf{A}$} & B & \multicolumn{2}{|c|}{$751,556,149$} \\
\hline & & & & & & & & \multicolumn{2}{|c|}{$\mathbf{C}$} \\
\hline \multicolumn{10}{|c|}{ by $10^{6}$} \\
\hline & $\mathrm{Z}_{\text {bottom }}=\mathrm{B} / \mathrm{A}$ & & & & 265 & $\mathrm{~cm}$ & & & \\
\hline & $\mathrm{I}=\mathrm{C}-\left(\mathrm{B}^{\wedge} 2 / \mathrm{A}\right)$ & & & & 707 & $\mathrm{~cm}^{4}$ & & & \\
\hline & $\mathrm{Z}_{\text {deck }}$ & & & & 310 & $\mathrm{~cm}$ & & & \\
\hline & $\mathrm{I}_{\text {deck }}$ & & & & 1254 & $\mathrm{~cm}^{4}$ & & & \\
\hline & $\mathrm{I}_{\text {bottom }}$ & & & & 1105 & $\mathrm{~cm}^{4}$ & & & \\
\hline \multicolumn{10}{|c|}{ Req. } \\
\hline & $\mathrm{W}_{\text {deck }}=\mathrm{I} / \mathrm{Zd}$ & & & 2.25 & 2.28 & $\mathrm{~cm}^{3}$ & & & \\
\hline & $\mathrm{W}_{\text {bottom }}=\mathrm{I} / \mathrm{Zb}$ & & & & 2.67 & $\mathrm{~cm}^{3}$ & & & \\
\hline
\end{tabular}

Total weight of the $100 \mathrm{~m}$ hull was calculated according to the drawing, shown in table 5. Material density is taken uniform and equal to that of construction steel, $\rho=7.9 \mathrm{~T} / \mathrm{m}^{3}$. The calculated estimated weight aligned well with the already known prototype ship hull weight. The real weight is $1200 \mathrm{~T}$. while the estimated hull weight is $1165 \mathrm{~T}$; The difference of $35 \mathrm{~T}$ is naturally explained by the brackets, deck equipment weight etc., therefore the estimated weight is accurate.

By analogy drawing was produced for the $50 \mathrm{~m}$ hull, it is similar albeit being cut in half and the carlings having the same section along their length. The calculated weight, shown in table 6 , is increased by $35 \mathrm{~T}$, as the ship still needs to have deck equipment. 
International Journal of Marine Engineering Innovation and Research, Vol. 6(3), Sept. 2021. 152-163

TABLE 4.

EQUIVALENT GIRDER CALCULATION FOR 50M VESSEL

\begin{tabular}{|c|c|c|c|c|c|c|c|c|c|}
\hline № & Element & Q-ty & Dim & & $F_{i}, \mathbf{c M}^{2}$ & $Z_{i}, \mathbf{c m}$ & $\mathrm{Fz}_{\mathrm{i}}, \mathbf{c m}^{\mathbf{3}}$ & $\mathrm{FZ}^{2}, \mathrm{~cm}^{4}$ & $i_{c}, \mathbf{c m}^{4}$ \\
\hline 1 & Bottom plating & 1 & 0.8 & 785 & 628 & 0.5 & 314 & 157 & 33 \\
\hline 2 & Double bottom plating & 1 & 0.8 & 859 & 687.2 & 65 & 44,668 & $2,903,420$ & 37 \\
\hline 3 & Bilge strake & 1 & 0.8 & 100 & 80 & 22 & 1760 & 38,720 & 33,333 \\
\hline 4 & Side plating & 1 & 0.8 & 290 & 232 & 283 & 65,656 & $18,580,648$ & $1,625,933$ \\
\hline 5 & Sheer strake & 1 & 1.4 & 210 & 294 & 470 & 138,180 & $64,944,600$ & $1,080,450$ \\
\hline 6 & Deck plating & 1 & 0.8 & 260 & 208 & 575 & 119,600 & $68,770,000$ & 11 \\
\hline 7 & Bottom stringers & 12 & \multicolumn{2}{|c|}{ HP14 ${ }^{\mathrm{a}}$} & 168.6 & 9.5 & 1,602 & 15,216 & 3,252 \\
\hline 8 & DB stringers & 12 & \multicolumn{2}{|c|}{ HP14 ${ }^{\mathrm{a}}$} & 168.6 & 58 & 9,779 & 567,170 & 3,252 \\
\hline 9 & Keel & 1.5 & 1 & 65 & 97.5 & 32.5 & 3,169 & 102,984 & 22,885 \\
\hline 11 & Side stringer hor. & 1 & 0.8 & 35 & 28 & 365 & 10,220 & $3,730,300$ & 2,858 \\
\hline 12 & Side stringer vert. & 1 & 1 & 15 & 15 & 365 & 5,475 & $1,998,375$ & 1 \\
\hline \multirow[t]{3}{*}{15} & Deck stringers & 4 & \multicolumn{2}{|c|}{ HP14 ${ }^{\mathrm{a}}$} & 56.2 & 1362.5 & 76,573 & 104330031 & 1,084 \\
\hline & & & & & 2,663 & & 476,995 & $265,981,622$ & $2,773,131$ \\
\hline & & & & & $\mathbf{A}$ & & B & \multicolumn{2}{|c|}{$268,754,753$} \\
\hline
\end{tabular}

$$
\begin{aligned}
& \mathrm{Z}_{\text {bottom }}=\mathrm{B} / \mathrm{A} \\
& \mathrm{I}=\mathrm{C}-\left(\mathrm{B}^{\wedge} 2 / \mathrm{A}\right) \\
& \mathrm{Z}_{\text {deck }} \\
& \mathrm{I}_{\text {deck }} \\
& \mathrm{I}_{\text {bottom }} \\
& \mathrm{W}_{\text {deck }}=\mathrm{I} / \mathrm{Zd} \\
& \mathrm{W}_{\text {bottom }}=\mathrm{I} / \mathrm{Zb}
\end{aligned}
$$

$\begin{array}{ccc} & \text { by } 10^{6} & \\ & 179 & \mathrm{~cm} \\ & 367 & \mathrm{~cm}^{4} \\ & 396 & \mathrm{~cm}^{4} \\ & 784 & \mathrm{~cm}^{4} \\ & 452 & \mathrm{~cm}^{4} \\ \text { Req. } & & \\ 0.41 & 0.93 & \mathrm{~cm}^{3} \\ & 2.05 & \mathrm{~cm}^{3}\end{array}$

The second design of a coupling mechanism provides a simple way to couple the barges.

These designs could be improved on and other designs could also be used to reap the benefits of compound barges, this is a topic for further research.

In part three, I calculated the hull weight economy, the estimated value of $50.7 \%$ is quite lucrative. It not only means fewer material costs but also that more cargo could be loaded onto the barge, further increasing its economic potential. However, in real ship design, this value will be less, as explained further.

It is also evident, that dividing the barges more e.g. 3 sections of $33 \mathrm{~m}$, is going to increase the percentage of hull weight economy up to the limit when the coupling device weight and ease of operation will prevail over the economy. How much is a topic for follow-up research.

Many of the RMRS [15] and other classification societies formulas for minimal values of thickness and moment of resistance of hull elements include ship length as a parameter, e.g. watertight bulkhead plating minimum thickness is found as RMRS formula 2.7.4.1-1:

$$
\mathrm{S}_{\min }=4+0.02 \mathrm{~L}
$$
three designs in table 8:

As can be seen, compound barge combines the benefits of long and short barges. In part one and two I have introduced two designs intending to achieve the required result.

The first design of a cover allows for a cost-effective way to reduce resistance while maintaining the seaworthy hull shape. where $\mathrm{L}$ - ship length between perpendiculars

It is common practice in shipbuilding to manipulate the frame spacing in a manner that allows for the actual plate thickness to be equal to minimum value stipulated by the classification society. It is then evident that reducing ship length may help to reduce the weight by reducing minimum thickness values. 
International Journal of Marine Engineering Innovation and Research, Vol. 6(3), Sept. 2021. 152-163 (pISSN: 2541-5972, eISSN: 2548-1479)

TABLE 5 .

WEIGHT CALCULATION OF 100 M HULL

\begin{tabular}{|c|c|c|c|c|c|}
\hline $100 \mathrm{~m}$ & $\begin{array}{l}\text { Q- } \\
\text { ty }\end{array}$ & $\mathrm{L}, \mathrm{m}$ & $\begin{array}{l}\mathrm{S}, \\
\mathrm{cm}^{2} \\
\end{array}$ & $\mathrm{~S}^{*} \mathrm{Q}, \mathrm{m}^{2}$ & $\begin{array}{l}\mathrm{P}= \\
\mathrm{SQL} \rho, \mathrm{T}\end{array}$ \\
\hline \multicolumn{6}{|l|}{ TRANSVERSE } \\
\hline Web frame & 50 & 5.1 & 43 & 0.215 & 8.7 \\
\hline Frame & 280 & 5.1 & 14.05 & 0.393 & 15.9 \\
\hline Half-beam & 50 & 2.315 & 43 & 0.215 & 3.9 \\
\hline Beam & 14 & 16.48 & 14.05 & 0.020 & 2.6 \\
\hline T.Coaming & 2 & 11.85 & 345 & 0.069 & 6.5 \\
\hline Floor & 23 & 14.4 & 72 & 0.166 & 18.8 \\
\hline Shelf & 7 & 16 & 86 & 0.060 & 7.6 \\
\hline Web rack & 21 & 5.1 & 43 & 0.090 & 3.6 \\
\hline Rack & 140 & 5.1 & 14.05 & 0.197 & 7.9 \\
\hline LONGITUDINAL & & & & PEtrans & 75.5 \\
\hline L.Coaming & 2 & 100 & 345 & 0.069 & 54.5 \\
\hline Carling 1 & 2 & 32.8 & 800 & 0.160 & 41.5 \\
\hline Carling 2 & 2 & 66.4 & 800 & 0.160 & 83.9 \\
\hline Carling 3 & 2 & 100 & 800 & 0.160 & 126.4 \\
\hline Carling 4 & 2 & 49.6 & 800 & 0.160 & 62.7 \\
\hline D. stringer 2 & 2 & 33.6 & 14.05 & 0.003 & 0.7 \\
\hline D. stringer 4 & 2 & 50.4 & 14.05 & 0.003 & 1.1 \\
\hline S. stringer & 2 & 97 & 86 & 0.017 & 13.2 \\
\hline Keel & 3 & 91.6 & 195 & 0.059 & 42.3 \\
\hline B. stringer & 22 & 91.6 & 14.05 & 0.031 & 22.4 \\
\hline DB. stringer & 22 & 92.5 & 14.05 & 0.031 & 22.6 \\
\hline PLATING & & & & PElong & 471.3 \\
\hline Deck & 1 & 100 & 1300 & 0.130 & 102.7 \\
\hline Sheer strake & 2 & 98 & 525 & 0.105 & 81.3 \\
\hline Side & 2 & 96 & 624 & 0.125 & 94.6 \\
\hline Double bottom & 1 & 92.5 & 1718 & 0.172 & 125.5 \\
\hline Bottom & 1 & 91.6 & 2512 & 0.251 & 181.8 \\
\hline \multirow[t]{3}{*}{ Bulkhead } & 7 & 14.4 & 408 & 0.286 & 32.5 \\
\hline & & & & 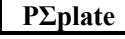 & 618.5 \\
\hline & & & & $\begin{array}{c}P^{100} \Sigma \text { total } \\
\text { D-P100 }\end{array}$ & $\begin{array}{r}1165 \\
35\end{array}$ \\
\hline
\end{tabular}

TABLE 6

WEIGHT CALCULATION OF $50 \mathrm{M}$ HULL

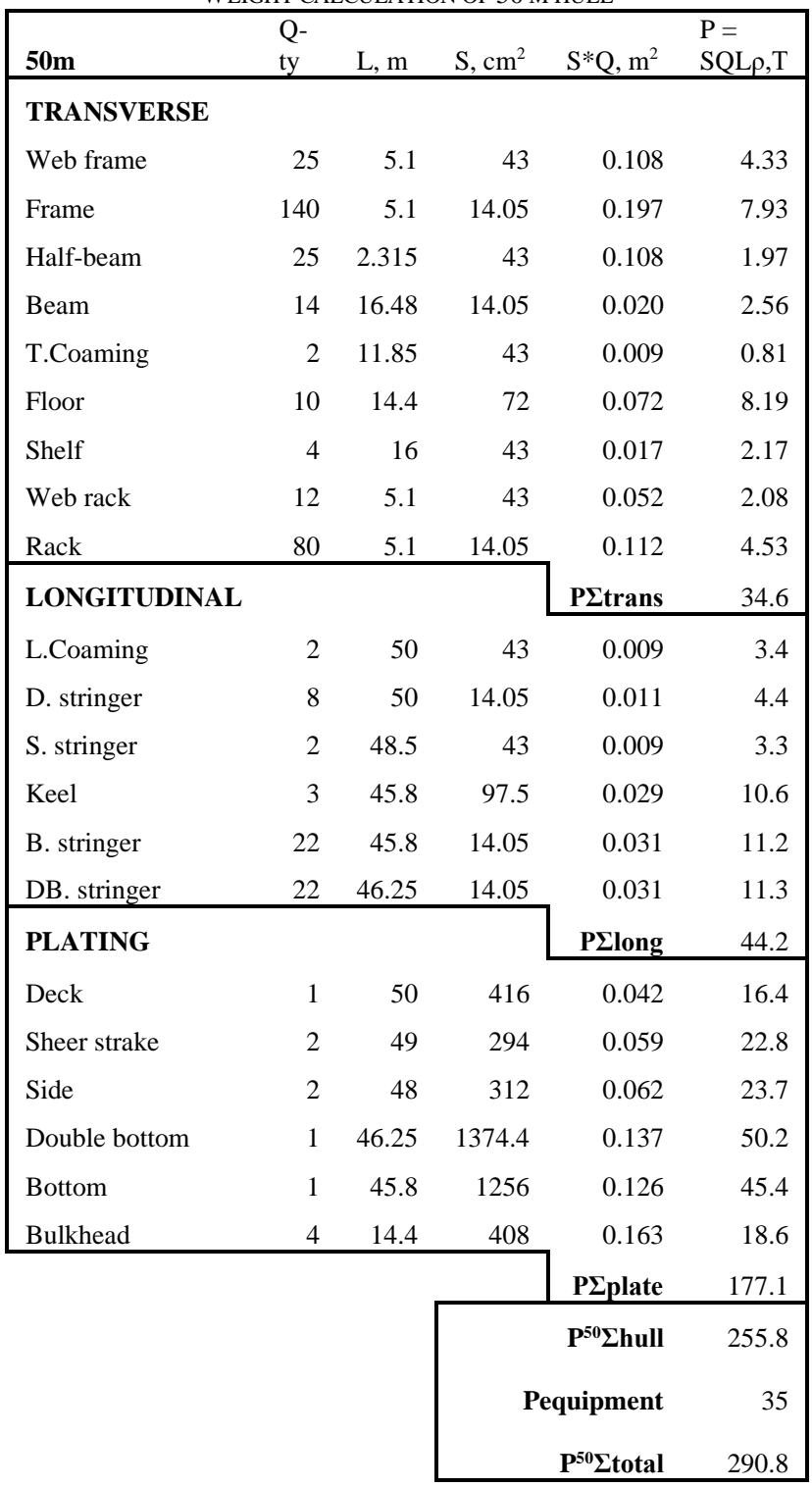

TABLE 7.

WEIGHT REDUCTION CALCULATION

\begin{tabular}{|c|c|c|}
\hline \multicolumn{3}{|c|}{ WEIGHT REDUCTION CALCULATION } \\
\hline $50 \mathrm{~m}$ weight & 290.8 & $\mathrm{~T}$ \\
\hline $2 \times 50 \mathrm{~m}$ weight & 581.7 & $\mathrm{~T}$ \\
\hline $100 \mathrm{~m}$ weight & 1200 & $\mathrm{~T}$ \\
\hline Coupler weight & 10 & $\mathrm{~T}$ \\
\hline Hull weight reduction & 608.3 & $\mathrm{~T}$ \\
\hline of $100 \mathrm{~m}$ weight & 50.7 & $\%$ \\
\hline
\end{tabular}

TABLE 8 .

DIFFERENCES BETWEEN COMPOUND VESSEL TYPES

\begin{tabular}{lccc}
\hline & $\begin{array}{c}\text { Single } \\
\text { long barge }\end{array}$ & $\begin{array}{c}\text { Compound } \\
\text { barge }\end{array}$ & $\begin{array}{c}\text { Two } \\
\text { short barges }\end{array}$ \\
\hline Weight & Heavy & Light & Light \\
Resistance & Small & Small & Big \\
\hline
\end{tabular}


The aforementioned patent [7] making use of special compound barge is another welcome advantage of compound barges, that as long as structurally feasible, could be incorporated into future vessels design.

This paper's results were subject to several assumptions and estimations, as such, the actual results on a newly designed ship may differ, the main points of attention are the following:

Several assumptions were made during the $50 \mathrm{~m}$ and $100 \mathrm{~m}$ hulls sections drawings design. In practice, the hulls would differ more; more effective designs of midships section and deck assembly would be devised; stronger materials would be used for the deck; loads would be distributed better. These factors will decrease the required moment of resistance and consequently, decrease the weight benefit estimated in this paper. These factors could not be estimated in the scope of this paper as they have to be decided during the design process of every unique vessel.

Manufacturing cost was not calculated, but the coupling device transport and installation should not cost more than the transport and installation of the longitudinal girders, the coupling device price will increase as the barge is divided into more sections. This is a topic for further practical research.

Attachment of the coupler to the hull and its strength should be evaluated more closely before an actual ship production.

The additional methodology will have to be developed by class societies for assessment of compounds vessels. It is an open question whether the vessel will be considered as a single ship or two ships by authorities.

Cargo compound barge is yet a novel concept that is part of growing compound vessels field of study, that can hopefully find its practical use in the changing shipbuilding industry.

\section{ACKNOWLEDGEMENTS}

Vladimir Chechkin, for invaluable consultation and suggestions on the design of the mechanical parts.

Alexander Demidiuk, for sharing his hydrodynamics lab research experience and knowledge on compound vessels.

Olexandr Kanifolskyi and Mikhail Tikhonov, for thoughtful comments and review.

\section{REFERENCES}

[1] Stankov B.N.; Russian Federation Patent No. RU 2551777; 2016; https://yandex.ru/patents/doc/RU2551777C1_20150527 (Accessed 12.11.2020)

[2] Yermolayev G.G., et al. "Морское судовождение” (Sеa navigation); $\quad 1970 ; \quad$ \$ 143 ; https://flot.com/publications/books/shelf/shipnavigation/index.htm (In Russian) (Accessed 12.11.2020) Translated: https://translate.google.com/translate?hl=\&sl=auto\&tl=en\&u=https $\% 3$ A\%2F\%2Fflot.com\%2Fpublications \%2Fbooks \%2Fshelf\%2Fshipnavig ation\%2Findex.htm

[3] Gruppman live journal; Bolsheretsk tragedy; https://gruppman.livejournal.com/158315.html (In Russian) (Accessed 12.11.2020) https://translate.google.com/translate $\mathrm{hl}=\& \mathrm{sl}=$ auto\&tl=en\&u=https $\% 3$ A\%2F\%2Fgruppman.livejournal.com\%2F158315.html

[4] Yegorova O.G.; “Совершенствование конструкции сухогрузных несамоходных речных судов для системы «Дунай Майн - Рейн»” (Structure improvement of dry bulk river barges for system "Danube-Main-Rhein"); Herald of the Odessa National

Maritime University No.52; 2017; http://www.meb.com.ua/onmu/201752.pdf (Accessed 12.11.2020)

[5] Yegorov A.G.; Analysis of couplers for sea and river tug-barge combinations; Herald of the Odessa National Maritime University No.42; 2014; http://www.meb.com.ua/onmu/201442.pdf (Accessed 12.11.2020)

[6] Korabel.ru; “Доклад по проектам перспективных ББС и составных судов для Днепра на ХІІ Международном симпозиуме инженеров-механиков ISUMEL-12" (Report on prospective projects of barge-tug combinations and compound vessel for navigation in Dnipro presented at XII International symposium of mechanical engineers ISUMEL-12); 2015 https://www.korabel.ru/news/comments/doklad_po proektam perspekt ivnyh bbs_i sostavnyh_sudov_dlya dnepra na xii mezhdunarodnom simpoziume inzhenerov-mehanikov isumel-12.html (In Russian) (Accessed 12.11.2020) Translated: https://translate.google.com/translate?hl=\&sl=auto\&tl=en\&u=https\%3 A\%2F\%2Fwww.korabel.ru\%2Fnews\%2Fcomments\%2Fdoklad_po_pr oektam_perspektivnyh_bbs_i_sostavnyh_sudov_dlya_dnepra_na_xii_ mezhdunarodnom_simpoziume_inzhenerov-mehanikov_isumel-

12.html

[7] Murtha C. Robert JR, McCormick E. Michael; "Articulating wave energy conversion system using a compound lever-arm barge”; US Patent No. US10359023B2; 2019; https://patents.google.com/patent/US10359023B2/en _Accessed 12.11.2020)

[8] Nibulon; Ships built at Nibulon wharf https://www.nibulon.com/data/sudnobuduvannya/vikonani-

zamovlennya.html (In Russian) (Accessed 12.11.2020) Translated: https://translate.google.com/translate?hl=\&sl=auto\&tl=en\&u=https $\% 3$ A \%2F\%2Fwww.nibulon.com\%2Fdata\%2Fsudnobuduvannya\%2Fviko nani-zamovlennya.html\%20

[9] Russian Maritime Register of Shipping; "Справочные данные по режиму ветра и волнения Балтийского, Северного, Черного, Азовского и Средиземного морей" (Data on wind and wave regimes of the Baltic, North, Black, Azov and Mediterranean seas); 2006; p.242

[10] Alexeyev G.M.; "Oсобые случаи морской практики” (Special $\begin{array}{lllll}\text { cases of sea } & \text { practice); } & 1959 ; & \$ 14\end{array}$ https://flot.com/publications/books/shelf/specialcases/16.htm (In Russian) (Accessed 12.11.2020) Translated https://translate.google.com/translate $\mathrm{hl}=\& s \mathrm{l}=$ auto\&tl=en\&u=https $\% 3$ A\%2F\%2Fflot.com\%2Fpublications \%2Fbooks\%2Fshelf\%2Fspecialcas es $\% 2 \mathrm{~F} 16 . \mathrm{htm}$

[11] «Mortechinformreklama»; "Практика управления морским транспортныл судном. Методические рекомендации” (Practice of sea cargo ship management. Methodical guidelines); 1984; https://studfile.net/preview/7168784/page:2/_In Russian) (Accessed 12.11.2020) Translated: https://translate.google.com/translate $\mathrm{hl}=\&$ sl=auto $\& \mathrm{tl}=\mathrm{en} \& \mathrm{u}=\mathrm{https} \% 3$ A\%2F\%2Fstudfile.net\%2Fpreview\%2F7168784\%2Fpage\%3A2\%2F

[12] Maхimaji A.I.; "Капитану о прочности судна. Справочник." (Captain's guide on ship strength);1988

[13] Kanifolskyi O.O.; "The relative section modulus of an equivalent girder for a deadrise hull vessel"; Herald of the Odessa National Maritime University No. 57; 2018; http://nbuv.gov.ua/jpdf/Vonmu 2018 4 5.pdf (Accessed 12.11.2020)

[14] Alferiyev M.Y.; “Ходкость и управляемость судов. Сопротивление воды движению судов" (Seaworthiness and handling of ships. Water resistance to ship movement); Moscow; Transport; 1967.

[15] Russian Maritime Register of Shipping; "Rules for the Classification and Construction of Sea-Going Ships, Part II Hull", 2020. https://lk.rsclass.org/regbook/rules;jsessionid=F92717B31C84F5C04C0B5381907 $\underline{29070 \text { (Accessed 12.11.2020) }}$ 